\title{
QUEEN'S
QNEIVERSITY
BELFAST
}

\section{Cooling and changing seasonality in the Southern Alps, New Zealand during the Antarctic Cold Reversal}

Vandergoes, M. J., Dieffenbacher-Krall, A. C., Newnham, R. M., Denton, G. H., \& Blaauw, M. (2008). Cooling and changing seasonality in the Southern Alps, New Zealand during the Antarctic Cold Reversal. Quaternary Science Reviews, 27(5-6), 589-601. https://doi.org/10.1016/j.quascirev.2007.11.015

Published in:

Quaternary Science Reviews

Document Version:

Publisher's PDF, also known as Version of record

Queen's University Belfast - Research Portal:

Link to publication record in Queen's University Belfast Research Portal

\section{General rights}

Copyright for the publications made accessible via the Queen's University Belfast Research Portal is retained by the author(s) and / or other copyright owners and it is a condition of accessing these publications that users recognise and abide by the legal requirements associated with these rights.

Take down policy

The Research Portal is Queen's institutional repository that provides access to Queen's research output. Every effort has been made to ensure that content in the Research Portal does not infringe any person's rights, or applicable UK laws. If you discover content in the Research Portal that you believe breaches copyright or violates any law, please contact openaccess@qub.ac.uk. 


\title{
Cooling and changing seasonality in the Southern Alps, New Zealand during the Antarctic Cold Reversal
}

\author{
Marcus J. Vandergoes ${ }^{\mathrm{a}, \mathrm{b}, *}$, Ann C. Dieffenbacher-Krall ${ }^{\mathrm{a}}$, Rewi M. Newnham ${ }^{\mathrm{c}}$, George \\ H. Denton ${ }^{\mathrm{a}, \mathrm{d}}$, Maarten Blaauw ${ }^{\mathrm{e}, 1}$ \\ ${ }^{a}$ Climate Change Institute, University of Maine, Orono, ME 04469, USA \\ ${ }^{\mathrm{b}}$ GNS Science, 1 Fairway Drive, Avalon, PO Box 30368, Lower Hutt, New Zealand \\ ${ }^{\mathrm{c}}$ School of Geography, University of Plymouth, Plymouth PL4 8AA, UK \\ ${ }^{\mathrm{d}}$ Department of Earth Sciences, University of Maine, Orono, ME 04469, USA \\ ${ }^{\mathrm{e}}$ Department of Earth Sciences, Uppsala University, Villavagen 16, SE-75236 Uppsala, Sweden
}

Received 10 July 2007; received in revised form 21 November 2007; accepted 23 November 2007

\begin{abstract}
A comprehensively ${ }^{14} \mathrm{C}$ AMS dated pollen and chironomid record from Boundary Stream Tarn provides the first chironomid-derived temperature reconstruction to quantify temperature change during Lateglacial times (17,500-10,000 cal yr BP) in the Southern Alps, New Zealand. The records indicate a ca 1000-year disruption to the Lateglacial warming trend and an overall cooling consistent with the Antarctic Cold Reversal (ACR). The main interval of chironomid-inferred summer temperature depression $\left(\sim 2-3{ }^{\circ} \mathrm{C}\right)$ lasted about 700 years during the ACR. Following this cooling event, both proxies indicate a warming step to temperatures slightly cooler than present during the Younger Dryas chronozone (12,900-11,500 cal yr BP). These results highlight a direct linkage between Antarctica and midlatitude terrestrial climate systems and the largely asynchronous nature of the interhemispheric climate system during the last glacial transition. The greater magnitude of temperature changes shown by the chironomid record is attributed to the response of the proxies to differences in seasonal climate with chironomids reflecting summer temperature and vegetation more strongly controlled by duration of winter or by minimum temperatures. These differences imply stronger seasonality at times during the Lateglacial, which may explain some of the variability between other paleoclimate records from New Zealand and have wider implications for understanding differences between proxy records for abrupt climate change.
\end{abstract}

(C) 2007 Elsevier Ltd. All rights reserved.

\section{Introduction}

The Antarctic Cold Reversal (ACR, 14,500-12,500 cal yr BP; EPICA Community Members, 2006) interrupted an otherwise progressive deglacial warming trend in most Antarctic ice core records (Petit et al., 1999; Blunier and Brook, 2001; Jouzel et al., 2001; EPICA Community Members, 2006). The ACR occurred during a time of marked climate fluctuations in the Northern Hemisphere that preceded the strong cooling in the North Atlantic region of the Younger Dryas (YD) chronozone $(12,900-11,500$ cal yr BP; Alley, 2000). However, the extent to which ACR patterns occurred through- out the Southern Hemisphere beyond the Antarctic region remains unclear (Heusser, 1998; McCulloch et al., 2000, 2005; Moreno et al., 2001; Hajdas et al., 2003; Mortyn et al., 2003; Lamy et al., 2004; Sugden et al., 2005; Barrows et al., 2007). In New Zealand, the debate as to the existence of an ACR-like cooling has not been resolved (Alloway et al., 2007). For example, recent New Zealand evidence has been interpreted as showing a southern (ACR-like) pattern (Turney et al., 2003; McGlone et al., 2004), a northern (Younger Dryas-like) signal (Denton and Hendy, 1994), or a climate signal intermediate between the ACR and the YD (Newnham and Lowe, 2000; Williams

\footnotetext{
*Corresponding author at: GNS Science, 1 Fairway Drive, Avalon, P.O. Box 30368, Lower Hutt, New Zealand. Tel.: +644570 4541; fax: +6445704600 .

E-mail addresses: vandergoes@maine.edu, m.vandergoes@gns.cri.nz (M.J. Vandergoes).

${ }^{1}$ Currently on leave at: Department of Archaeology and Paleoecology, Queen's University Belfast, UK.
} 
et al., 2005; Hajdas et al., 2006). Differences among these records may be attributed to various factors including the extent to which these climate events influence sites that extend across a broad latitudinal range, chronologic control of the stratigraphic sequences, and sampling resolution. However, these differences may also involve the individual response of proxies to climate change. Fluctuations in climate parameters such as precipitation, temperature minima and maxima, and changes in the seasonal variability of climate patterns (seasonality) are all likely to influence biota in different ways. A multi-proxy approach, involving more than one biotic element, therefore, can potentially provide greater insight into the response of different proxies to climate change; the detail of past climate change; and hence promote understanding of their causes.

This paper presents a ${ }^{14} \mathrm{C}$ Accelerator Mass Spectrometry (AMS)-dated, high resolution, multi-proxy paleoecological record (pollen and chironomid) that makes use of a recently developed chironomid-inferred temperature model (Dieffenbacher-Krall et al., 2007) to derive and quantify Lateglacial climate change at Boundary Stream Tarn in the Southern Alps, New Zealand. The results, indicating significant differences in seasonal climate patterns superposed on a predominantly Antarctic-like signal, provide new perspectives on the Lateglacial transition in the southern mid-latitudes and may help explain some of the complexity observed in Lateglacial records from the southern mid-latitudes.

\section{New Zealand climate reversal during the Lateglacial}

Evidence for climate reversal during the Lateglacial transition in New Zealand has emerged only recently. The Southern Alps have a widespread system of Lateglacial moraines (e.g. Waiho Loop/Canavans Knob, Birch Hill, Prospect Hill, and Arthur's Pass). Limiting minimum ages of as much as $12,400\left(\mathrm{Be}^{10}\right)$ years come from both the Birch Hill moraines at Lake Pukaki and the Lake Misery moraines at Arthur's Pass (Ivy-Ochs personal communication, Ivy-Ochs et al., 1999). Numerous radiocarbon $\left({ }^{14} \mathrm{C}\right)$ dates of wood from the base of a till sequence at Canavans Knob suggest ice advance toward the Waiho Loop moraine at $11,100{ }^{14} \mathrm{C}$ yr BP $(13,000$ cal yr BP; Denton and Hendy, 1994) while $\mathrm{Be}^{10}$ ages from the moraine crest are interpreted as indicating ice retreat from this feature during the early Holocene $(10,480 \pm 240$ cal yr BP; Barrows et al., 2007). From these ages, it is not yet clear if the Lateglacial advance occurred at the beginning of the Northern Hemisphere YD or the end of the ACR in the south. Recent modelling of the Franz Josef Glacier (Anderson and Mackintosh, 2006) suggests that a $3-4{ }^{\circ} \mathrm{C}$ cooling is required to advance the glacier to its Lateglacial limits at the Waiho Loop moraine. High-resolution $\delta^{18} \mathrm{O}$ records from speleothems also indicate environmental change between ca 13,800 and $11,140 \mathrm{cal} \mathrm{yr}$ BP with a positive $\delta^{18} \mathrm{O}$ excursion that provides supporting evidence for regional ice advance (Hellstrom et al., 1998; Williams et al., 2005). A Lateglacial temperature reversal of $\sim 2{ }^{\circ} \mathrm{C}$ between ca 14,000 and 13,000 cal yr BP is also indicated in a marine record off the east coast of the South Island (Pahnke et al., 2003; Pahnke and Zahn, 2005).

Evidence of a cooling reversal during the Lateglacial transition also comes from pollen records located in climatically sensitive areas such as at high elevation, or at an ecotonal boundary where a relatively minor climatic change has significant impact. These records, including those from Kaipo Bog (Newnham and Lowe, 2000; Hajdas et al., 2006), Otamangakau and Kettlehole Bog (Turney et al., 2003; McGlone et al., 2004), show an interval of about 1000 years when percentages of tree/shrub pollen declined and herbaceous pollen increased. Constraining radiocarbon ages place these events between 13,800 and 12,400 cal yr BP at Kaipo Bog, 14,700 and 13,000 cal yr BP at Otamangakau, and 14,600 and 13,300 cal yr BP at Kettlehole Bog. The records show discernable shifts in pollen assemblages that largely antedate or barely overlap the early YD; hence they may be comparable to cooling initiated during the ACR. At other New Zealand pollen sites not situated at high altitude or ecotonal boundaries, Lateglacial reversal of deglacial warming is either minor (e.g. Newnham et al., 2007a,b) or not apparent (e.g., McGlone, 1995; Vandergoes and Fitzsimons, 2003).

\section{Site significance and description}

The Pukaki Basin in the central South Island (Fig. 1) lies directly south of the highest ranges in the New Zealand Southern Alps. These mountains intercept the prevailing westerly air flow to produce a strong west-to-east precipitation and temperature gradient and a characteristically dry climate to the east of the ranges. These climate gradients are sensitive to subtle changes in the circumpolar westerlies, which are directly linked to Antarctic air masses (Chinn, 1999; Lamont et al., 1999; Clare et al., 2002). Paleoclimate proxies from sites within this area should be highly sensitive to shifts in precipitation and temperature associated with past changes in intensity and latitude of the westerly wind systems.

The eastern central South Island generally has warm summers and mild winters. Mean annual air temperatures are about $8.8^{\circ} \mathrm{C}$ (Mt. Cook township and Tekapo climate stations), with February (summer) and July (winter) means ranging between 15.1 and $1.7^{\circ} \mathrm{C}$, respectively (New Zealand National Climate Centre, 2007). Extreme temperatures are between 33.3 and $-15^{\circ} \mathrm{C}$ in the area. Mean annual precipitation ranges from $4293 \mathrm{~mm}$ close to the Southern Alps (Mt. Cook township) to $600 \mathrm{~mm}$ some $30 \mathrm{~km}$ to the south east of the Southern Alps at Tekapo.

The geomorphology of the Pukaki Basin is dominated by glacial moraines and outwash plains of the last glaciation and by Holocene alluvial fans. Both Last Glacial Maximum (LGM) and Lateglacial moraines are common 


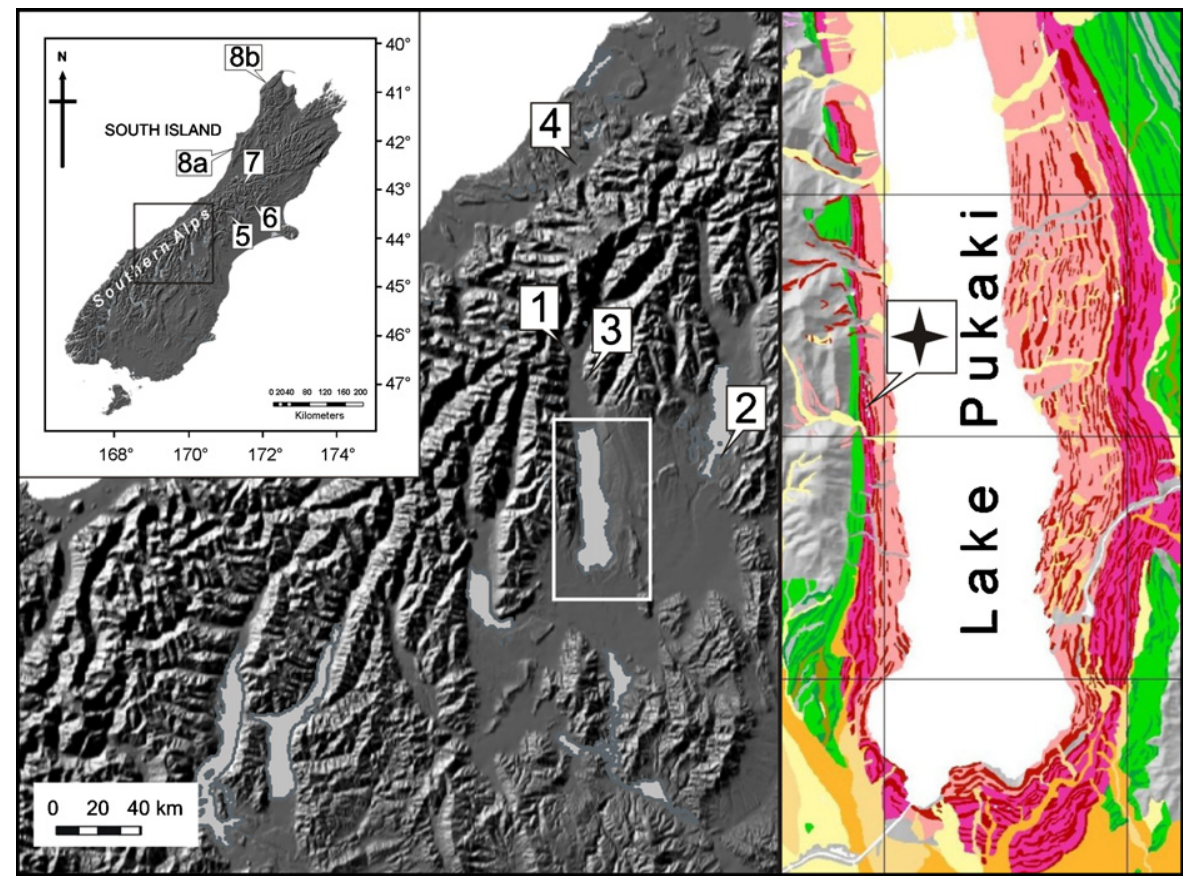

Fig. 1. Location of study area in South Island, New Zealand and other sites mentioned in the text. Boundary Stream Tarn (star) in the Pukaki Basin; 1, Mt. Cook township; 2, Tekapo; 3, Birch Hill; 4, Canavans Knob; 5, Prospect Hill; 6, Kettlehole Bog; 7, Arthur's Pass; 8a-b, South Island speleothems. For moraine classification see Schaefer et al. (2006).

(Fig. 1; Ivy-Ochs et al., 1999; Schaefer et al., 2006). The present-day vegetation of the basin has been highly modified by natural and recent anthropogenic fires. Pollen evidence indicates that the area was dominated by podocarp scrubland, primarily Phyllocladus alpinus, from ca $8000 \mathrm{yr}$ BP until $5000 \mathrm{yr}$ BP, after which Halocarpus bidwilli and grassland communities became prolific in the landscape as a result of drought and fire (McGlone and Moar, 1998). The podocarp scrubland has been further reduced to grassland by fire and land clearance by Maori and Europeans over the past 800 years. The present vegetation is tussock grassland (Chionochloa rigida, Poa colensoi) above the treeline in the alpine zone, and grassland-shrubland (Festuca novae-zelandiae, Discaria tomatou, Dracophyllum, Hebe, and Coprosma spp.) on the lower slopes and valley floor. Small stands of Halocarpus, Phyllocladus, and Nothofagus forest survive as remnant patches (McGlone and Moar, 1998).

Boundary Stream Tarn $\left(44^{\circ} 02^{\prime} \mathrm{S}, 170^{\circ} 07^{\prime} \mathrm{E} ; 830 \mathrm{~m}\right.$ elevation) is one of a cluster of small kettle lakes within a lateral moraine complex of LGM age (Schaefer et al., 2006). Aside from ephemeral drainage input from a small neighboring tarn, Boundary Stream Tarn is devoid of major sedimentary or fluvial influence. The kettle lakes are located in the present montane-to-subalpine vegetation zone and should be ideally placed to provide evidence of past fluctuations in tree line and temperature. Mean annual precipitation at the site, estimated from climate surface models, is $1268 \mathrm{~mm}$ (Leathwick et al., 1998). Mean annual air temperature is estimated to be $7.7^{\circ} \mathrm{C}$ and mean summer and winter temperatures 13.4 and $2.8^{\circ} \mathrm{C}$, respectively.

\section{Methods}

To reconstruct and quantify Lateglacial climate change, fossil chironomid larval remains were analyzed from overlapping sediment cores recovered from Boundary Stream Tarn. Pollen analysis was also conducted to provide an independent proxy of Lateglacial vegetation and climate change and to evaluate the structure and timing of changes produced by the chironomid record. Four sediment cores were recovered with a square rod, piston corer from the deepest area of the lake in proximity to each other. All four cores show a consistent stratigraphy. Two cores (0201 and 0408), that represent the entire Lateglacial sequence, were sampled for pollen and chironomids and used to establish chronology. Samples were taken at 8 and $4 \mathrm{~cm}$ intervals throughout the cores to provide the basic pollen and chironomid stratigraphy for the site. Sections showing marked stratigraphic change, radiocarbon dated to the time of the ACR, were resampled at 1 and $2 \mathrm{~cm}$ intervals for detailed analyses.

Pollen extraction was carried out using standard laboratory techniques $(10 \%$ hot $\mathrm{KOH}, 40 \% \mathrm{HF}$, and acetolysis; Faegri et al., 1989). Samples were spiked with exotic Lycopodium spores for calculation of pollen concentrations. Pollen identifications were made using standard texts (e.g. Pocknall, 1981a-c; Large and Braggins, 1991; Moar, 1993) and the New Zealand pollen reference collection held at the University of Plymouth. Grass pollen grains (Poaceae) were divided by size, greater than and less than $40 \mu \mathrm{m}$, to distinguish between tall tussock Chionochloa grassland $(>40 \mu \mathrm{m})$ components and short 
tussock $(<40 \mu \mathrm{m})$ grassland components (McGlone and Moar, 1998; McGlone, 2001). For each sample, pollen taxon values were expressed as percentages of a minimum pollen sum of 250 grains. This sum included pollen from all dryland plants except pteridophytes.

Chironomid samples were prepared using standard laboratory techniques $(5 \%$ warm $\mathrm{KOH}$, sieved through $90 \mu \mathrm{m}$ mesh; e.g. Walker et al., 1991; Brooks and Birks, 2000). Chironomid remains were picked from water using a modified Bogorov tray, placed in water drops on glass slides, and fixed using Pro-Texx mounting medium following the evaporation of water. Chironomid taxon values were expressed as percentages of a minimum sum of 50 head capsules from each sample. Chironomid identification followed Forsyth (1971), Boothroyd (1994, 1999, 2002, 2004, unpub.), Stark and Winterbourn (2006) and our own identification guide (http://www.climatechange.umaine.edu/ Research/facilities/perl/nzguide.html). All Chironomus specimens had fewer than 60 striae on the ventromental plates (Martin and Forsyth, 2006) and are consistent with the "Chironomus spp." of Woodward and Shulmeister (2006).

We applied the weighted average partial least squares (WA-PLS 3 component) and partial least squares (PLS 3 component) inference models of Dieffenbacher-Krall et al. (2007) to infer mean summer temperature values (Fig. 2). The models have coefficients of determination $\left(r_{\mathrm{jack}}^{2}\right)$ of 0.80
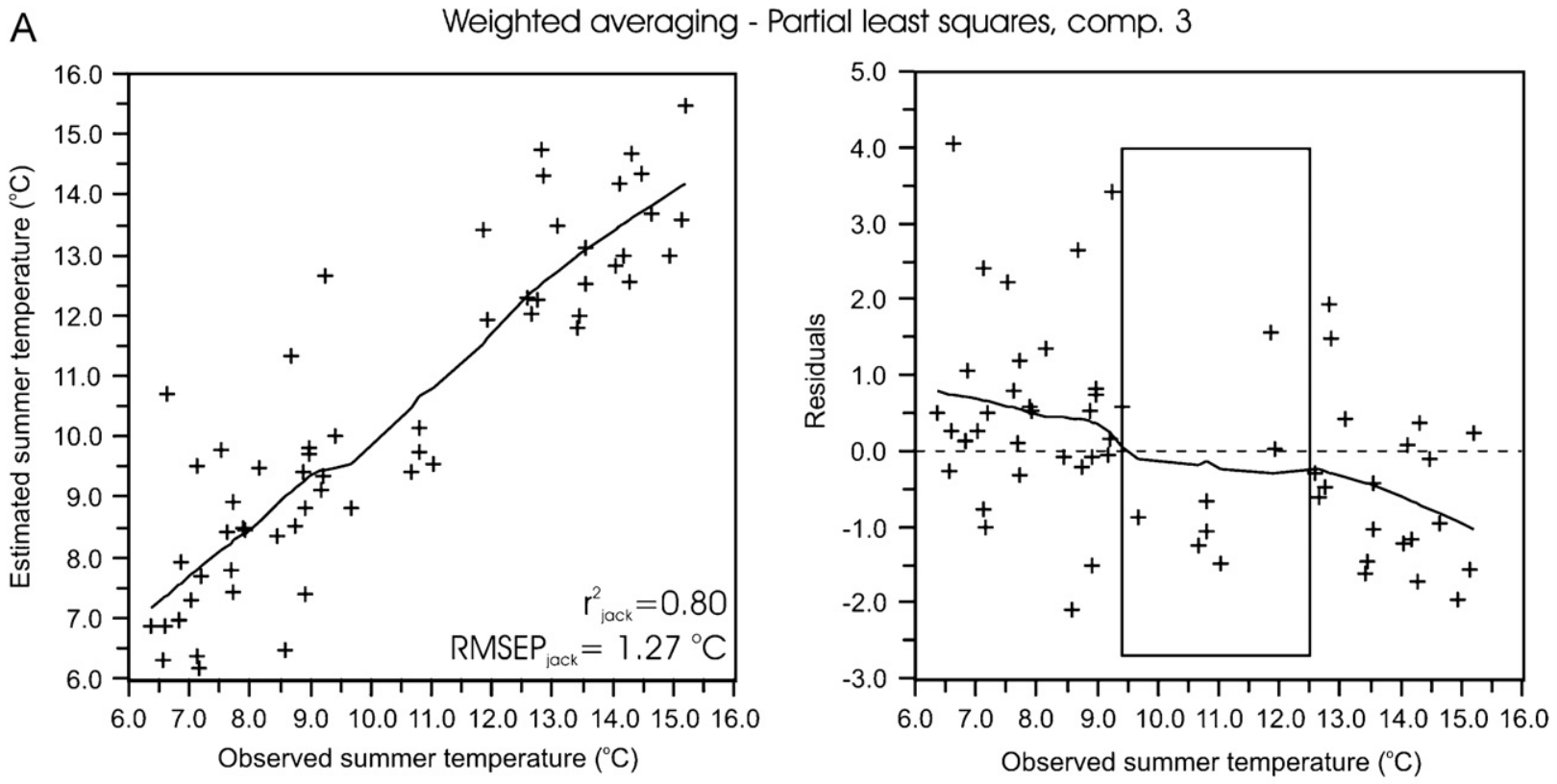

B

Partial least squares, comp. 3
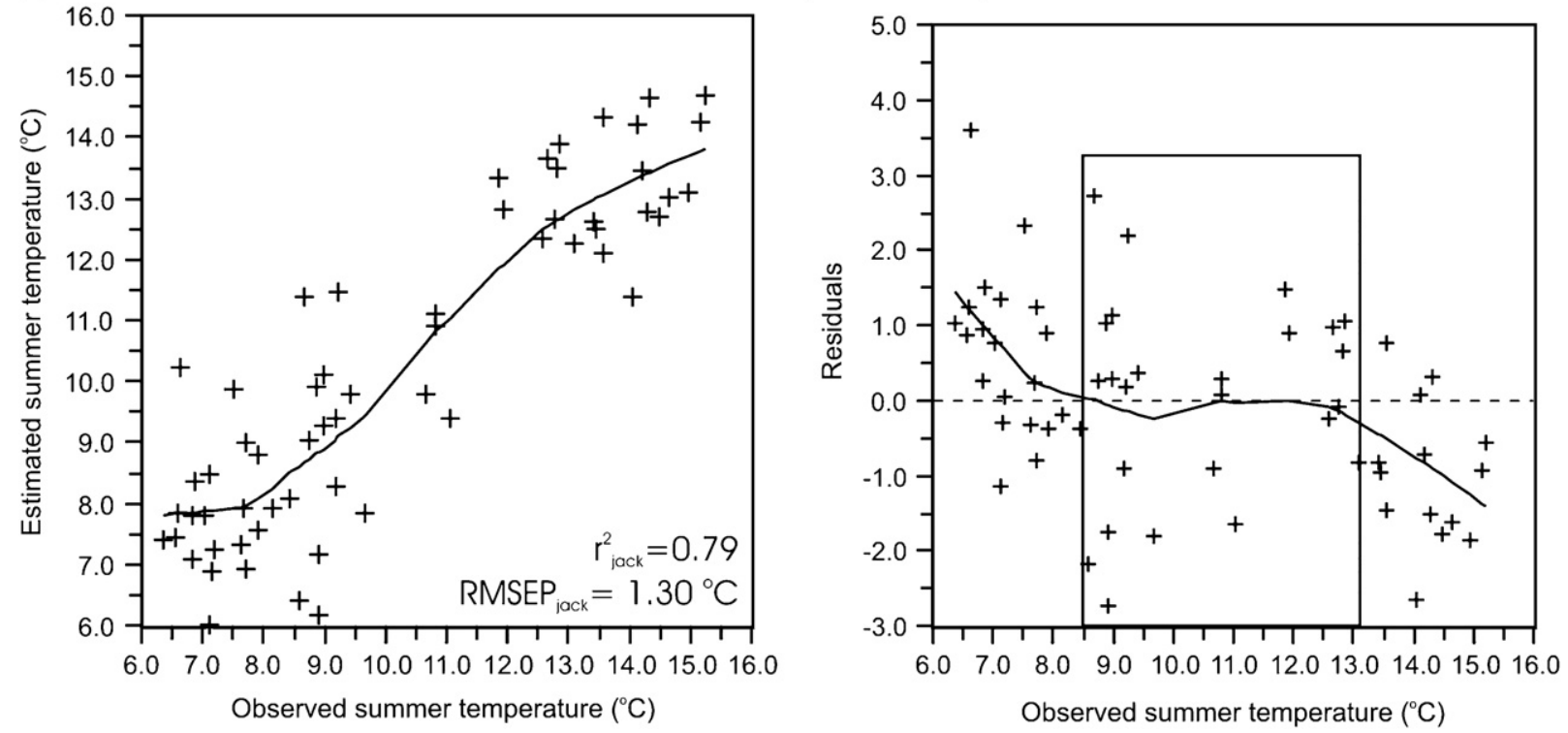

Fig. 2. Observed versus predicted temperatures and plots of residual errors for (A) the WA-PLS and (B) the PLS models. A LOWESS smooth (0.45) and rectangle boxes in the residual plots highlight the ranges of best prediction for each model and show the number of lakes used to derive temperature predictions through this range (from Dieffenbacher-Krall et al., 2007). 
and 0.79 , and root mean square errors of prediction $\left(\mathrm{RMSEP}_{\text {jack }}\right)$ of 1.27 and $1.30{ }^{\circ} \mathrm{C}$, respectively. Both models were applied to the fossil chironomid data from Boundary Stream Tarn to assess the reconstructive power of each model.

\subsection{Radiocarbon dates and age model}

Seventeen AMS ${ }^{14} \mathrm{C}$ dates were obtained on organic material in 1-cm-thick slices of bulk sediment (Table 1). All ages have been reported in calibrated years, unless otherwise noted. The age model (Fig. 3a and b) was developed using the Bayesian software Bpeat (Blaauw and Christen, 2005) and contains the following five assump- tions. The first two assumptions relate to the depositional setting at the site and indicate that: (i) the depositional setting dictates that the dated depths must be ordered chronologically; (ii) the deposition rates of ca $20-80 \mathrm{yr} / \mathrm{cm}$ are considered most likely, but other (positive) accumulation rates are possible (priors mean and range 50 respectively 25). Two further assumptions relate to the occurrence of hiatuses and indicate that: (iii) the variable stratigraphy suggests that rapid accumulation rate changes and hiatuses could have occurred (prior variance 2); (iv) the hiatuses were most likely to be very short, but could at times have lasted millennia (priors skewedness and width both 0.0005 ). The final assumption deals with outlying dates and indicates that: (v) the dates had a prior

Table 1

Radiometric dates of cores 0201 and 0408 from boundary stream

\begin{tabular}{|c|c|c|c|c|c|c|c|c|c|}
\hline Core & $\begin{array}{l}\text { Sub-bottom } \\
\text { depth }(\mathrm{cm}) \text { core } \\
0201\end{array}$ & $\begin{array}{l}\text { Sub-bottom } \\
\text { depth }(\mathrm{cm}) \\
\text { relative to } 0201 \\
\text { from } 0408\end{array}$ & ${ }^{14} \mathrm{C}$ lab \# & $\begin{array}{l}\text { Carbon } \\
\text { combusted } \\
(\mathrm{mg})\end{array}$ & $\mathrm{CO}_{2}(\mu \mathrm{mol})$ & $\delta^{13} \mathrm{C}$ & ${ }^{14} \mathrm{C}$ age & $\pm 1 \sigma$ & $\begin{array}{l}\text { Calibrated age } \\
\text { range } 2 \sigma\end{array}$ \\
\hline 0201 & 308 & & Wk-10719 & Unavailable & Unavailable & -29.9 & 9991 & 77 & $11,239-11,805$ \\
\hline 0201 & 316 & & OS-37971 & 7.62 & 119.5 & -24.42 & 10,100 & 40 & $11,404-11,968$ \\
\hline 0201 & 317 & & OS-42553 & Not weighed & 39.2 & -28.15 & 9870 & 65 & $11,180-11,601$ \\
\hline 0201 & 333 & & OS-42661 & 12.7 & 110.5 & -20.73 & 10,200 & 45 & $11,718-12,078$ \\
\hline 0201 & 334 & & OS-37972 & 13.37 & 129.1 & -21.09 & 10,400 & 50 & $12,077-12,595$ \\
\hline 0408 & & 360 & OS-48412 & 109.15 & 247.6 & -22.36 & 10,350 & 55 & $11,985-12,665$ \\
\hline 0408 & & 380 & OS-46017 & 114.22 & 137.9 & -21.9 & 11,100 & 70 & $12,890-13,139$ \\
\hline 0408 & & 380 & OS-45812 & 42.61 & 179.8 & -22.11 & 11,150 & 45 & $12,939-13,154$ \\
\hline 0201 & 382 & & OS-38191 & 25.73 & 116.6 & -21.43 & 11,050 & 65 & $12,876-13,093$ \\
\hline 0201 & 394 & & OS-42662 & 18.74 & 122.8 & -21.86 & 10,800 & 60 & $12,734-12,893$ \\
\hline 0201 & 410 & & OS-38192 & 34.64 & 157.3 & -22.72 & 12,150 & 70 & $13,827-14,164$ \\
\hline 0408 & & 410 & OS-45813 & 261.78 & 275 & -22.99 & 12,300 & 45 & $14,012-14,546$ \\
\hline 0408 & & 410 & OS-46018 & 124.83 & 144.8 & -23.07 & 12,300 & 60 & $13,999-14,611$ \\
\hline 0408 & & 450 & OS-48413 & 27.2 & 220.5 & -21.63 & 12,600 & 55 & $14,473-15,126$ \\
\hline 0201 & 483 & & OS-42663 & 21.45 & 143.1 & -20.13 & 13,200 & 60 & $15,288-16,012$ \\
\hline 0201 & 528 & & OS-38193 & 30.54 & 195.5 & -19.71 & 14,100 & 65 & $16,379-17,183$ \\
\hline 0201 & 532 & & OS-42664 & 27.19 & 97.1 & -18.93 & 14,800 & 65 & $17,661-18,486$ \\
\hline
\end{tabular}

Calibrated age ranges $(2 \sigma)$ are calculated for all ages using INTCAL04 (Reimer et al., 2004). Samples were submitted to the National Ocean Sciences AMS Laboratory, Woods Hole Oceanographic Institution, Massachusetts, USA (OS) and the Radiocarbon Dating Laboratory, University of Waikato, Hamilton, New Zealand (Wk) for conventional radiocarbon analysis. Bulk organic material from core sediment samples were combusted for this analysis.

A

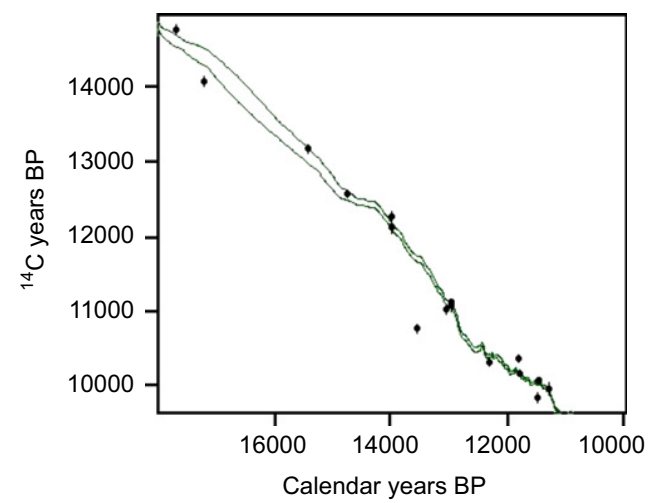

B

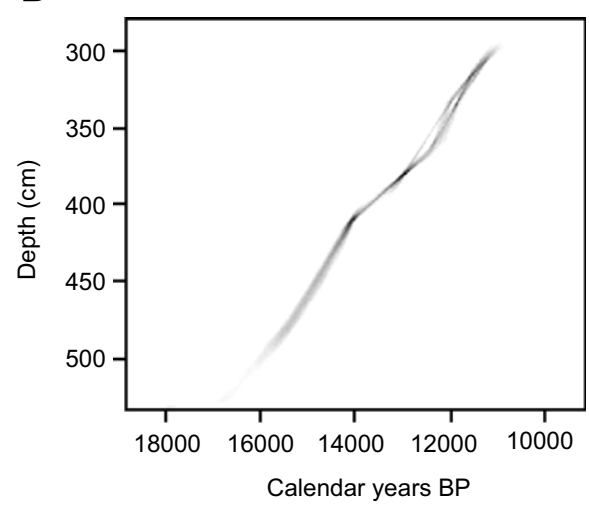

Fig. 3. (A) Boundary Stream Tarn ages in relation to INTCAL04 radiocarbon calibration curve. (B) Grayscale age model developed for Boundary Stream Tarn. Areas of best prediction are indicated by darkest gray. 
probability of $5 \%$ of being an outlier. Outlying dates were not removed manually but were identified and downweighted automatically by the software. We used the INTCAL04 calibration curve (Reimer et al., 2004) to calibrate all ${ }^{14} \mathrm{C}$ dates and corrected for a Southern Hemisphere offset of $41 \pm 14{ }^{14} \mathrm{C}$ years (McCormac et al., 2002). We applied 12 section breaks to obtain an age model based on linear interpolation between the dated levels. The best age model, with associated uncertainties was constructed by running one billion Monte Carlo Markov Chain iterations (Blaauw and Christen, 2005). The results provide a rigorous and continuous age model that spans $17,500-10,000$ cal yr BP.

\section{Results}

\subsection{Sediment stratigraphy}

The basal sediment between 530 and $520 \mathrm{~cm}$ is composed of stiff gray diamicton (Fig. 4). This diamicton is similar to that in nearby moraine outcrops and is likely to represent underlying moraine. The sediment between 520 and $466 \mathrm{~cm}$ is comprised of light brown banded and unbanded silts. Most of the core between 466 and $317 \mathrm{~cm}$ features brown organic silt. However, significant changes in stratigraphy occur between 410 and $383 \mathrm{~cm}$ and between 317 and $334 \mathrm{~cm}$, where gray-brown and light brown silt layers are prominent. The upper sediment of the sequence between 317 and $280 \mathrm{~cm}$ is composed of brown fibrous silt.

\subsection{Dating and chronology}

The AMS ${ }^{14} \mathrm{C}$ ages, calibrated using INTCAL04, show strong internal consistency (Fig. 3a). Multiple dates from the same horizon above and below the major sediment changes at $410,380,333-334$ and $317 \mathrm{~cm}$ provide nearidentical or overlapping dates ( $2 \sigma$ range; Table 1$)$. The consistency of these ages tightly constrains these sediment changes in the sequence. Two ages (OS 42553, OS 42662) were identified as outliers by the modelling analysis (Table 1, Fig. 3a). These ages were not removed from subsequent analysis but their importance for constructing the age model was down-weighted. The age model shows a strong predictive fit between the ages in the sequence (Fig. 3b) and produces robust estimates for the timing of reconstructed environmental change.

\subsection{Pollen and chironomid stratigraphy}

Pollen of subalpine shrubland and alpine grassland (Poaceae, Asteraceae, Myrsine, and Coprosma) dominate the sequence from 17,500 to $14,200 \mathrm{cal}$ yr BP, with grassland pollen being most abundant from 17,500 to 15,500 cal yr BP (Fig. 4). Chironomid analysis reveals a mixture of taxa between 17,500 and 14,200 cal yr BP. Taxa widespread in cool to warm lakes today (Tanytarsus funebris types A-1 and C-1) are common as well as Chironomus, which is dominant in high-altitude, lowtemperature lakes today (Dieffenbacher-Krall et al., 2007).

The interval between 14,100 and 13,100 cal yr BP shows distinctive changes in the pollen and chironomid records, as well as in the sediment stratigraphy. This interval is marked by the increase in tall Chionochloa alpine tussock (Poaceae $>40 \mu \mathrm{m}$ ) and grassland-open herbfield pollen (Poaceae $<40 \mu \mathrm{m}$, Asteraceae), and decrease in low shrubland species (Coprosma). The increase in alpine tussock pollen and associated grassland-herbfield pollen changes are indicative of expanding alpine environments and a return to conditions similar to those experienced before $15,000 \mathrm{cal}$ yr BP when grassland pollen levels were at similar levels. A change in sediment stratigraphy from organic silt to alternating layers of organic and inorganic silt occurs at this time and coincides with a marked increase in aquatic pollen spores of Isoetes and Botryococcus. The interval between 14,100 and 13,100 cal yr BP also displays significant change in the chironomid assemblage with elevated levels of taxa more tolerant of low temperatures, notably Chironomus and Tanytarsus funebris-type C-s, and wide temperature ranges (Apsectrotanypus) which may become more abundant where less tolerant species decline.

The first appearance, decline, and subsequent increase of Corynocera and Paucispinigera taxa more commonly associated with lower altitude temperate environments (Dieffenbacher-Krall et al., 2007), also occurs between 14,100 and 13,100 cal yr BP.

The decline in relative abundance of grassland-open herbfield pollen beginning at $13,100 \mathrm{cal}$ yr BP is followed by increases in pollen of the shrub conifers (Halocarpus, Phyllocladus) at 12,800 and 11,900 cal yr BP, respectively. These pollen changes imply replacement of open grassland and shrubland communities by woody vegetation near the site. A decline of cold tolerant chironomids and an increase of warm temperate types Corynocera and Polypedilum occurred between 13,200 and 13,100 cal yr BP. Corynocera becomes a dominant component of the assemblage after 13,000 cal yr BP. A sedimentary change from organic to inorganic silt occurs between 12,000 and $11,500 \mathrm{calyr}$ BP and corresponds with a slight increase in Tanytarsus funebris-type C-1. Increases in tall podocarp pollen (Podocarpus, Prumnopitys taxifolia) after 11,000 cal yr BP suggest that the succession of conifer forest continued near the site, with tall podocarp trees increasing in importance in the Phyllocladus shrub forest. There is little variation in the chironomid record during this time, aside from a slight increase in Tanytarsus funebris-type B.

\subsection{Chironomid inferred temperature reconstructions- model evaluation}

Both the WA-PLS and PLS (Fig. 4) models produce a nearly identical structure of paleotemperature change during the Lateglacial transition. However, the temperatures 
predicted by the WA-PLS predictions are generally $1-2{ }^{\circ} \mathrm{C}$ cooler than those of the PLS model. Temperature estimates range from 13.2 to $8.1^{\circ} \mathrm{C}\left( \pm 1.4^{\circ} \mathrm{C}\right.$ sample specific error $)$ for the WA-PLS and $14.1-9.5^{\circ} \mathrm{C}\left( \pm 1.6^{\circ} \mathrm{C}\right.$ sample specific error) for the PLS model, thus displaying strong overlap within the error ranges of each model. Relative to the mean modern summer air temperature at this site $\left(13.4^{\circ} \mathrm{C}\right)$, reconstructed temperatures reach a maximum of $2.3^{\circ} \mathrm{C}$ warmer and $6.7^{\circ} \mathrm{C}$ cooler between 17,500 and 11,000 cal yr BP.

Both reconstructions show generally cool temperatures between 17,500 and 15,500 cal yr BP, followed by warming until 14,200 cal yr BP. A subsequent cooling began after 14,200 . By 14,000 cal yr BP the reconstructed temperatures were similar to, or slightly cooler than, those at around 16,000 cal yr BP. This initial cooling was interrupted by a sharp rise in temperature to their highest levels, of Lateglacial times, about $13,900 \mathrm{cal} \mathrm{yr} \mathrm{BP}$, followed by the resumption of cooling until $13,200 \mathrm{calyr} \mathrm{BP}$. A rapid rise in temperature occurred at around 13,200 cal yr BP, after which temperatures increase slightly (WA-PLS model) or cool slightly (PLS model) until ca 11,500 cal yr BP. These differences between model reconstructions for the interval ca 13,200-11,500 cal yr BP are well within the error margins of each reconstruction. Taken together, the two reconstructions suggest a period of comparatively little change in mean summer temperature; however, the individual reconstructed temperature estimates may indicate some degree of variability between 12,000 and $11,500 \mathrm{cal}$ yr BP. A cooling trend is indicated at the top of the sequence. Although age control here is imprecise, this cooling may have occurred after ca 11,200 cal yr BP.

To evaluate the models, we consider how well they predict modern temperature from the original New Zealand lake data set (Fig. 2) over the ranges shown in the paleotemperature reconstruction. The plot of observed against estimated temperatures and residuals errors for each model suggests that the PLS model may provide the best temperature estimate within the range of $8.5-13{ }^{\circ} \mathrm{C}$. The WA-PLS model performs best in the range of $9.5-12{ }^{\circ} \mathrm{C}$, although it may be more likely to underestimate temperatures in this range than the PLS model (Dieffenbacher-Krall et al., 2007). This may be because the PLS model utilizes a larger suite of lakes than the WAPLS model to develop temperature estimates throughout its range of best prediction $\left(8.5-13{ }^{\circ} \mathrm{C}\right)$. Therefore, we adopt the PLS model for the chironomid-derived summer temperature reconstruction here, in conjunction with the pollen record, to determine the paleoclimate history for the site. However, temperature estimates produced by both models between 10 and $12{ }^{\circ} \mathrm{C}$ are derived from a small number of lakes in the modern data set, which may affect the robustness of the temperature predictions in this range. Both models tend to underestimate the warm range $\left(>13^{\circ} \mathrm{C}\right)$ and overestimate the cool range $\left(<8^{\circ} \mathrm{C}\right)$, as is typical for such models (e.g. Birks, 2003).

\subsection{Paleotemperature reconstructions 17,500-10,000 cal yr BP}

The age of ca $17,500 \mathrm{cal}$ yr BP for the basal sediments in this sequence provides a minimum estimate for the onset of deglaciation from glacial maximum limits in the upper Pukaki Basin. This is consistent with exposure age estimates for major ice recession from terminal moraine limits in the lower Pukaki Basin (Schaefer et al., 2006) and with evidence from throughout New Zealand for a major change in climate around 18,000 cal yr BP that terminated the last major glacial episode (Newnham et al., 2003, 2007a; Alloway et al., 2007). Nevertheless, at Boundary Stream Tarn, absence of tall forest and dominance of subalpine shrubland and alpine grassland between 17,500 and $14,200 \mathrm{cal}$ yr BP indicates that climate regimes were cooler and more extreme than at present. Chironomid inferred mean summer temperatures increased from 11 to $12.7^{\circ} \mathrm{C}$ during this time, $0.7-2.4^{\circ} \mathrm{C}$ lower than the presentday mean summer temperature of $13.4^{\circ} \mathrm{C}$ (Fig. 4).

The minor expansion of tall tussock alpine grassland at ca 14,100 cal yr BP is indicative of a return to conditions similar to (or cooler than) those between 17,500 and $15,500 \mathrm{cal}$ yr BP. An increase in inorganic sediment after 14,100 cal yr BP may result from enhanced weathering and erosion due to frost heave and vegetation changes near the site. Increased aquatic plant pollen and spores (e.g. Isoetes) and colonial algae (e.g. Botryococcus); indicate greater prevalence of both running and ponded water at the site during this time. Chironomid temperature reconstructions indicate that cooling began at ca $14,200 \mathrm{cal}$ yr BP and by ca 14,000 cal yr BP temperatures had decreased to $11.5-12$, or $1.5-2{ }^{\circ} \mathrm{C}$ below modern summer air temperature. A shortlived interruption to this cooling trend occurred about $13,900 \mathrm{cal} \mathrm{yr} \mathrm{BP}$, when mean summer temperature increased to around $13.5^{\circ} \mathrm{C}$, at or slightly above its present-day level (Fig. 4). Within 100 years or so, pronounced cooling resumed for ca $600-700$ years. During this interval, average mean summer temperatures dropped to around $10.5-11.4{ }^{\circ} \mathrm{C}$, with extreme cool temperatures reconstructed from one sample approximating $9.5^{\circ} \mathrm{C}$. These temperatures were generally $2.0-2.9^{\circ} \mathrm{C}$ below the present day and in the most extreme case as much as $3.9^{\circ} \mathrm{C}$ lower.

A marked abrupt warming from ca 11.4 to ca $12.6^{\circ} \mathrm{C}$ at ca 13,200 cal yr BP is evident in the chironomid summer temperature reconstruction and is followed by an interval $(13,100-11,500$ cal yr BP) when the two climate proxies may have responded differently. The pollen record indicates sequential replacement of grassland/shrubland communities by Halocarpus-dominated subalpine conifer forest. This vegetation development is evident in other pollen records from the region (e.g. McGlone et al., 2004) and has been interpreted as indicating increasing minimum winter or spring temperatures. In contrast, chironomid reconstructions show no clear temperature trend between 13,000 and 11,500 cal yr BP, but some variability associated with an 


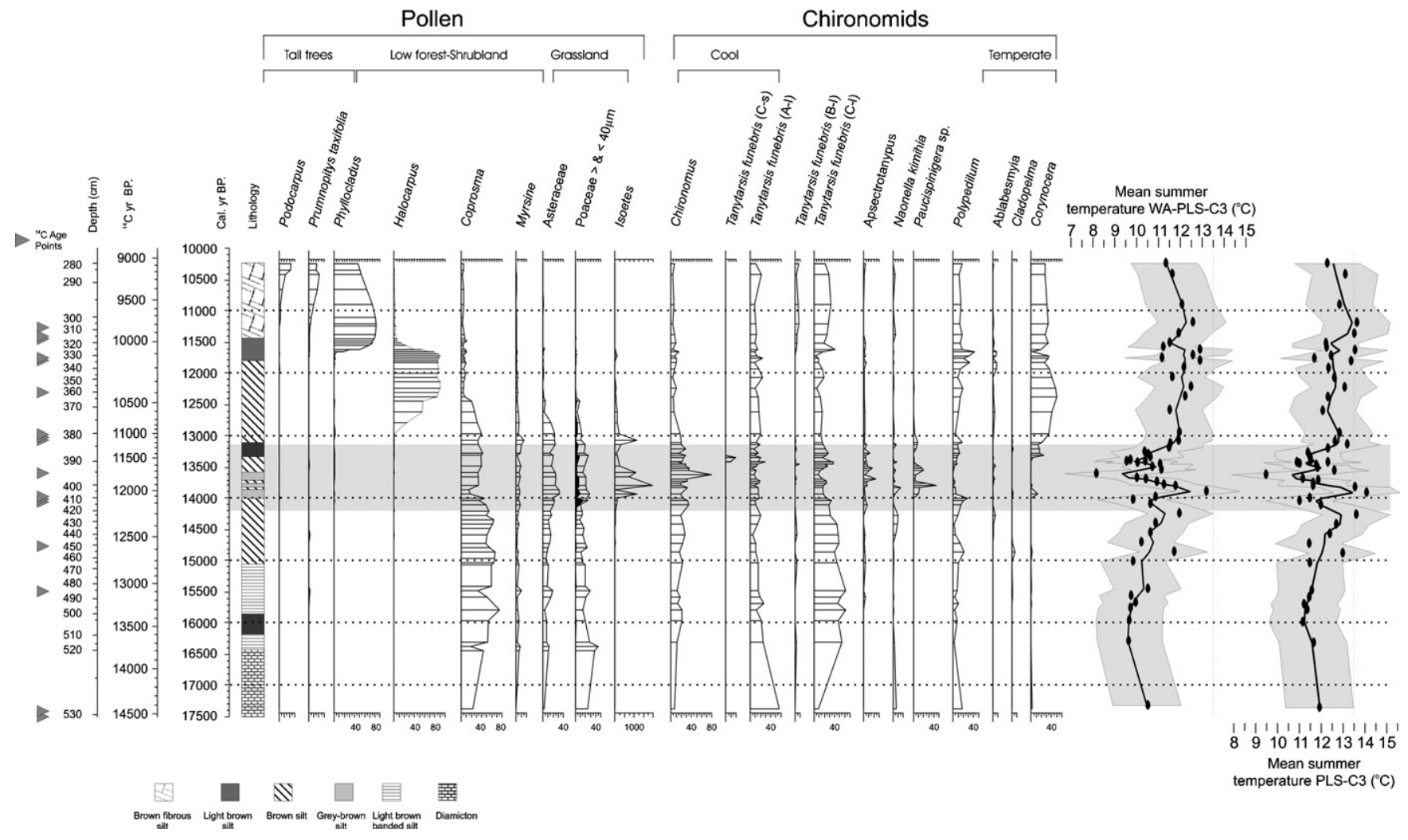

Fig. 4. Summary pollen and chironomid diagram for Boundary Stream Tarn. Dark shading on the Poaceae pollen curve represents grains greater than $40 \mu \mathrm{m}$, characteristic of tall Chionochloa tussock grassland. Both WA-PLS and PLS model reconstructions are shown. A LOWESS smooth (0.1) has been fitted to highlight the major trends and sample specific errors are shown by light shading on each reconstruction. Vertical line on the temperature reconstructions at $13.4^{\circ} \mathrm{C}$ represents present mean summer temperature at the site. The pollen and chironomid diagrams represent only those species that occur in abundances $>5 \%$ or provide information directly relevant for Lateglacial environmental and climate reconstruction in the area. Taxa excluded from this figure are shown in supplementary Fig. 1. Gray shading represents zone of Lateglacial change in sediment stratigraphy, and pollen and chironomid assemblages.

increase in inorganic silt between 12,000 and 11,500 cal yr BP. During the interval 13,000-11,500 cal yr BP, temperatures fluctuated between 11.6 and $13.8^{\circ} \mathrm{C}$, averaging around $12.5^{\circ} \mathrm{C}$ or about $1.0^{\circ} \mathrm{C}$ below present (Fig. 4). These differences between chironomid and pollen-vegetation response imply a minor decoupling of summer and winter temperature trends during this interval. Alternatively the differences may be due to variable response times between the two proxies to the abrupt warming evident in the chironomid temperature reconstructions at 13,200 cal yr BP. In this scenario, the chironomids responded rapidly to the abrupt warming while the pollen record showed a more lagged response, which eventually results in successional replacement of grassland-shrubland communities with subalpine conifer forest.

After 11,600 cal yr BP, a general rise of temperature to values near those of today is indicated in the chironomid reconstructions. The rapid transition from Halocarpusdominated to Phyllocladus-dominated subalpine conifer forest after $11,500 \mathrm{cal}$ yr BP is a feature evident in other South Island pollen diagrams (e.g. Burrows and Russell, 1990; McGlone et al., 2004). The vegetation change appears to be a precursory development of tall forest and is considered to represent a shift to temperatures similar to the present. Marked changes are also recorded in the sediment stratigraphy at this time with a transition from inorganic to organic fibrous silt, indicative of sustained catchment stability.

In summary, the multi-proxy record from Boundary Stream Tarn offers new insights into patterns of Lateglacial climate change in the Pukaki Basin. Following deglacial warming from ca $17,000 \mathrm{cal} \mathrm{yr} \mathrm{BP}$, the pollen and chironomid evidence collectively indicates a period of markedly fluctuating, but overall cooler, temperatures from 14,200 to 13,200 cal yr BP, broadly coinciding with the ACR. This cooler period includes at least one pronounced fluctuation evident in the chironomid record but not the pollen record, when chironomid-derived temperatures increased by $2-3{ }^{\circ} \mathrm{C}$ and then fell by a similar or greater amount during the interval ca 14,000-13,600 cal yr BP. Both paleoecological proxies, together with the sediment stratigraphy, strongly suggest that this was a period of relative climate instability.

This period of cooling and instability was terminated by an abrupt warming, accompanied by increased stability in the catchment at ca $13,200 \mathrm{calyr}$ BP. This warming step was followed by an interval broadly coinciding with the Younger Dryas chronozone, from 13,000 to $11,500 \mathrm{cal}$ yr BP, when the inferred temperature changes from pollen and chironomids may show minor differences. 
Gradual changes from the pollen record during this time versus rapid changes in the chironomid record at the beginning of this interval suggest that summer temperatures, indicated by the chironomid reconstructions, remained comparatively stable with only brief periods of variability while minimum temperatures in winter and spring, indicated by pollen-vegetation developments, increased. Alternatively, the differences may be due to variable response times between the two proxies; the chironomids responded rapidly to the abrupt warming whilst the pollen-vegetation showed a lagged response, eventually resulting in the successional development of subalpine conifer forest.

Finally, at ca 11,500 cal yr BP, a further warming step is evident in both the pollen record and chironomid temperature reconstruction. These changes, together with the shift to fibrous organic sediment indicate further increases in summer temperatures, catchment stability and a major transition in subalpine forest composition at the site.

The next section considers the broader implications of these insights into Lateglacial climates facilitated by the Boundary Stream Tarn records, through comparison with other records from the New Zealand region.

\section{Discussion}

\subsection{Lateglacial cooling in the Southern Alps, New Zealand}

A Lateglacial cooling event, broadly comparable to that evident in the Boundary Stream Tarn records is observed in several other high-resolution records from New Zealand (e.g. Newnham and Lowe, 2000; Pahnke et al., 2003; McGlone et al., 2004; Pahnke and Zahn, 2005; Vandergoes et al., 2005; Williams et al., 2005; Newnham et al., 2007b; Fig. 5).

The cooling indicated by the pollen and chironomid records from Boundary Stream Tarn (ca 14,200-13,200 cal yr BP) broadly coincides with other pollen-based evidence of Lateglacial climate reversal from the eastern margins of the Southern Alps (Moar, 1971; McGlone et al., 2004) dated between 14,600 and 13,000 cal yr BP (McGlone et al., 2004). Cooling centered on 13,600 cal yr BP is also shown by mean annual air temperature estimates from a recently developed pollen-temperature calibration model (Wilmshurst et al., 2007). These records provide strong evidence of a regional climate cooling event. Climate cooling between 14,100 and $13,000 \mathrm{cal}$ yr BP is indicated by the marine oxygen isotope and reconstructed sea surface temperature records from MD97 site 2120 (Fig. 5) off the east coast of the South Island (Pahnke et al., 2003; Pahnke and Zahn, 2005). The dating control for cooling between ca 14,200 and 13,200 cal yr BP provided by the Boundary Stream Tarn chronology strengthens the assertion that cooling occurred about this time, as noted in the marine record. The onset of the Boundary Stream Tarn cooling event predates by ca 600 years the cooling signal indicated by high-resolution pollen evidence from Kaipo Bog north-eastern New Zealand (Newnham and Lowe, 2000, Hajdas et al., 2006), and South Island speleothems (Williams et al., 2005; Fig. 5), although it

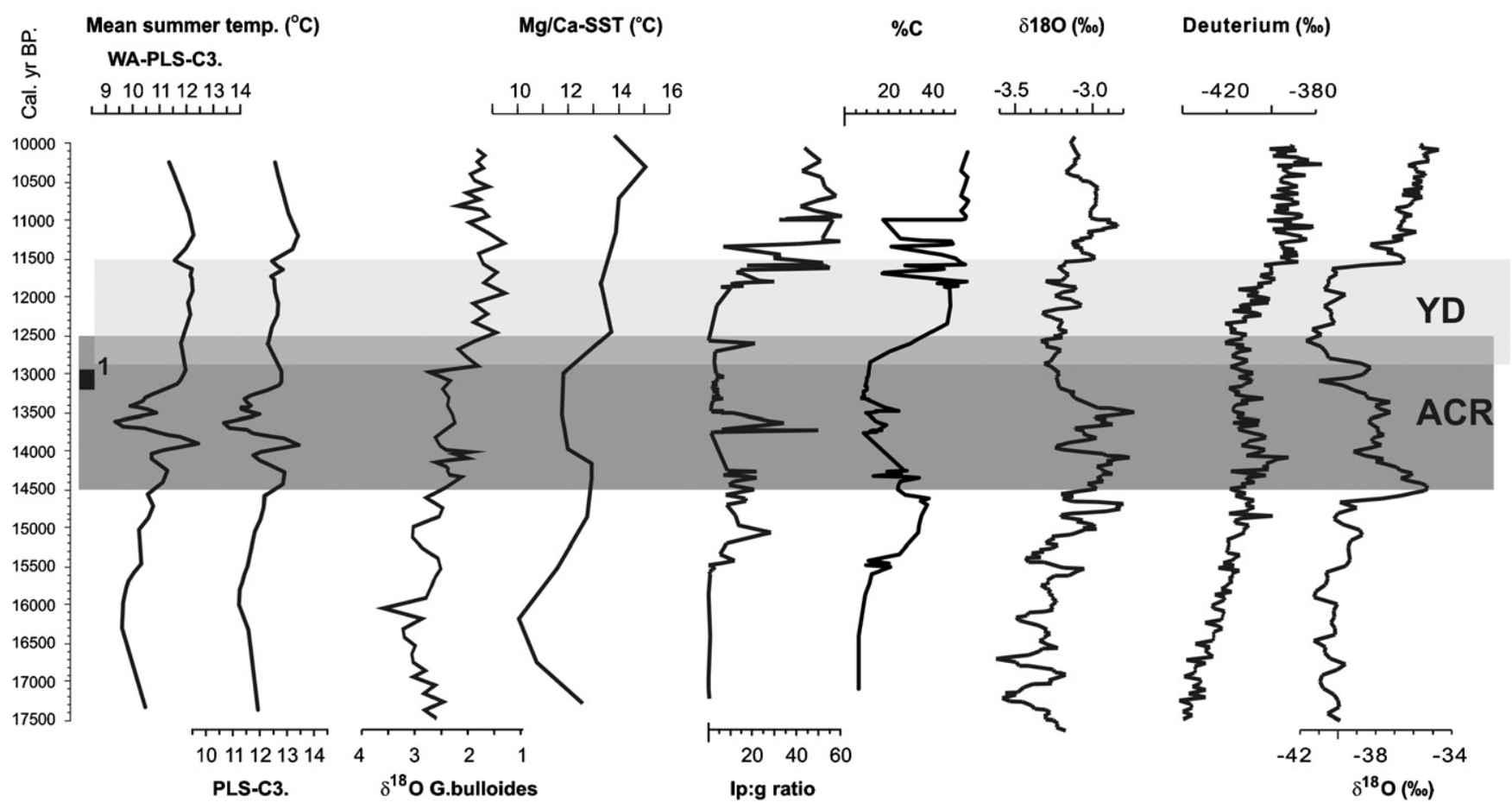

Fig. 5. (A) Boundary Stream Tarn chironomid temperature records as compared to (B) marine oxygen isotope and SST reconstruction from MD97-2120 (Pahnke and Zahn, 2005), (C) Kaipo Bog lowland pollen: grassland ratio and percentage carbon record (Newnham and Lowe, 2000), (D) composite South Island speleothem record (Williams et al., 2005), (E) EPICA Dome C Deuterium excess record (EPICA Community Members, 2006), and (F) Greenland GISP 2 oxygen isotope record (Alley, 2000). Black bar (1) represents the Lateglacial advance of the Franz Josef Glacier over Canavans Knob (Denton and Hendy, 1994). The ACR and YD are represented by overlapping shaded bars. 
is possible that these events may be more closely aligned when chronological error margins are taken into account. As the onset of cooling in the Kaipo Bog and speleothem records shows strong correspondence with the coldest phase of cooling in the Boundary Stream Tarn record between 13,900 and $13,200 \mathrm{calyr} \mathrm{BP}$, it seems probable that these two events are linked.

The termination of Boundary Stream Tarn cooling (after 13,200 cal yr BP) antedates the end of cooling observed in Kaipo Bog by ca 600 years (approximately 12,600 cal yr BP; Newnham and Lowe, 2000; Hajdas et al., 2006). Cooling is indicated to have persisted for another 1600 years (until $11,600 \mathrm{cal} y \mathrm{BP}$ ) in the South Island speleothem record (Williams et al., 2005). The termination of the Boundary Stream Tarn cooling event coincides with well-dated till deposits at Canavans Knob indicating an advanced position of the Franz Josef Glacier at 13,100 cal yr BP (Denton and Hendy, 1994).

The Lateglacial cooling interval at Boundary Stream Tarn, dated at 14,200 to ca 13,200 cal yr BP, falls within the ACR recorded in Antarctic ice cores, broadly dated as 14,500-12,500 cal yr BP (EPICA Community Members, 2006). Thus evidence from Boundary Stream Tarn indicates that the ACR signal extended into southern New Zealand. There is no clear evidence that this climate reversal persisted into the YD chron. However, the PLS chironomid temperature estimates indicate that mean summer temperatures remained about $1{ }^{\circ} \mathrm{C}$ cooler than present for the interval 13,100-11,500 cal yr BP, after which summer temperatures became more similar to those of the present day. In contrast, the pollen assemblages are consistent with others from this region and show vegetation changes interpreted as progressive increase in minimum winter or spring temperatures throughout this interval or, alternatively, a warming step at ca 13,200 cal yr BP sufficient to trigger the slightly lagged successional development of low forest. The former explanation implies strong seasonal differences occurred during this interval, whereas the latter interpretation would indicate similar patterns between seasons but with the vegetation developments lagging the chironomid response to abrupt warming at ca $13,200 \mathrm{cal}$ yr BP.

Regardless of which of these interpretations is favored, a slightly cooler than present, climate over New Zealand between 13,100 and 11,500 cal yr BP may help explain evidence of prolonged cooling from other high-resolution records such as the persistence of the cooling reversal at Kaipo Bog to ca 12,600 cal yr BP (Hajdas et al., 2006), and of the 'New Zealand Lateglacial Reversal' identified in South Island speleothems lasting to ca $11,600 \mathrm{cal} \mathrm{yr} \mathrm{BP}$ (Williams et al., 2005). In both these studies, cooling appears to have been initiated during the ACR but extended into either part or all of the YD chron. This evidence contrasts with interpretations from earlier New Zealand studies which imply that the YD was a period of gradual warming (e.g. McGlone, 1995; McGlone et al., 2004). By indicating that the transition from ACR to YD may have been characterised by an abrupt warming step, followed in some regions at least by slightly cooler-thanpresent temperatures during the YD, the Boundary Stream Tarn record provides a potential explanation for this conflict. Clearly the presence at times of variable and slightly cooler climate between 13,100 and 11,500 cal yr BP needs to be corroborated by other multi-proxy investigations from climatically sensitive sites.

The magnitude of the Lateglacial cooling trend in summer temperatures at Boundary Stream Tarn $\left(2.9-2{ }^{\circ} \mathrm{C}\right.$ below present, PLS model) is less than the range of likely temperature decreases $\left(3-4.7^{\circ} \mathrm{C}\right)$ and combined precipitation increases indicated in recent modelling of Lateglacial ice advance of the Franz Josef Glacier (Anderson and Mackintosh, 2006). The ice modelled temperature reconstructions are more consistent with the possible extreme cooling value $\left(-3.9^{\circ} \mathrm{C}\right)$ indicated by the chironomid PLS model and the average trend range of the WA-PLS model $\left(-2.7-4.2^{\circ} \mathrm{C}\right)$ reconstructions for this site. The cooling trend at Boundary Stream Tarn is more comparable with an approximate $2.5^{\circ} \mathrm{C}$ cooling noted in a marine record off the east coast (Pahnke et al., 2003; Pahnke and Zahn 2005; Fig. 5). Regional temperature depressions below presentday values in southern New Zealand may not have been more extreme than the $2.5^{\circ} \mathrm{C}$ derived from marine core proxies. However, if the modern climate-temperature gradients from immediately east of the Southern Alps to the east coast of the South Island persisted in the past, it is likely that inland regions of southern New Zealand experienced more extreme climates and temperature depressions than the lowland and coastal maritime areas. A scenario of more extreme inland climates in the past resulting from a depressed or intensified east-west climate gradient would accommodate the prediction errors associated with the chironomid reconstructions of both PLS and WAPLS models. Consistency between the chironomid PLS model results and other quantitative temperature estimates from New Zealand, such as sea surface temperature reconstructions, supports the current use of this model for Lateglacial temperature reconstructions.

\subsection{Lateglacial shifts in seasonality}

A notable difference between the Boundary Stream Tarn pollen record and chironomid-based temperature estimates occurs between 14,000 and 13,800 cal yr BP. An abrupt warming event represented in the chironomid temperatures and driven by minor increases in Corynocera, Naonella kimihia and Paucispinigera sp. is not shown in the pollen record. It is possible that this warming event was too short-lived to have impacted on local vegetation, but alternatively it may indicate differences in biotic response to climate change. Chironomids show the strongest relationship to mean summer temperature (Dieffenbacher-Krall et al., 2007). In contrast, New Zealand vegetation, with its low freezing resistance (Wardle, 1991), is likely to be strongly controlled by the duration of winter or 
annual minimum temperatures. The difference between the pollen and chironomid results may indicate seasonal climate variability, in which summers were short and warm and winters cold or prolonged, resulting in short vegetation growing seasons. This interpretation implies more extreme seasonality between 14,200 and 13,100 cal yr BP than prior to 14,200 cal yr BP, when both summer and winter temperatures seem to have been generally cool. After 13,100 cal yr BP, seasonal variability or a more parallel relationship between summer and winter temperatures may equally explain the differences between the pollen and chironomid signals.

The warming at Boundary Stream Tarn between 14,000 and $13,800 \mathrm{calyr}$ BP may be similar to other events recorded in other sites around New Zealand. For example, an increase in lowland pollen and organic carbon in a North Island pollen sequence (Newnham and Lowe, 2000), and a positive excursion in the $\delta^{18} \mathrm{O}$ from South Island speleothems (Williams et al., 2005) and the offshore east coast marine record (Pahnke et al., 2003; Pahnke and Zahn, 2005; Fig. 5) may represent warming in these records. Minor differences in timing of this event among these records are likely to be within the error margins of the dating control. In each case, the warming event appears to be a precursor to the subsequent ACR-like cooling and therefore the two phenomena may be linked. Further investigations are necessary to confirm the timing and distribution of this abrupt warming event.

\section{Conclusions}

The Boundary Stream Tarn sedimentary sequence shows that deglaciation from glacial maximum limits indicated by the Pukaki lateral moraines commenced prior to ca 17,500 cal yr BP. This is consistent with the timing of major recession from terminal moraines down valley and with comparable evidence from elsewhere in New Zealand. The chironomid temperature reconstruction at this site represents the first of its kind for the Lateglacial in New Zealand, and provides a quantitative assessment of climate change for this time period. While the chironomidderived reconstruction generally confirms the pattern of temperature change inferred from pollen, differences in the structure and possible magnitude of cooling are indicated. These minor differences between the two proxies are likely to reflect seasonal climate variations although a lagged vegetation response to abrupt climate change may also be a factor. Both seasonal differences in climate and a lagged vegetation-climate response may be contributing factors to the variability thus far observed between other proxy records for Lateglacial climate reversal in New Zealand. The ${ }^{14} \mathrm{C}$ AMS-derived chronology constrains the timing of Lateglacial cooling in the Southern Alps of New Zealand to the ACR. The Boundary Stream Tarn record thus supports an ACR-like climate reversal in southern New Zealand and an antiphased relationship between AntarcticNew Zealand and Northern Hemisphere climate at this time. A possible abrupt warming event, occurring around the onset of the ACR in the Boundary Stream Tarn chironomid reconstructions, may have correlatives in other New Zealand records and should be a focus of further investigation.

\section{Acknowledgments}

We thank the late Gary Comer for his generous support of climate change research and this study. Financial support for this research came from the Comer Science and Education Foundation, National Oceanic and Atmospheric Administration, the National Science Foundation, and the Natural Environment Research Council. The authors gratefully acknowledge G. and M. Seymore for access to site, Chris Hendy and Tom Lowell for assistance with core recovery in the early stages of the project and laboratory technicians Joshua Munyon, Amanda French, and Steven Barteaux.

\section{Appendix A. Supplementary data}

Supplementary data associated with this article can be found in the online version at doi:10.1016/j.quascirev. 2007.11.015.

\section{References}

Alley, R.B., 2000. The Younger Dryas cold interval as viewed from central Greenland. Quaternary Science Reviews 19, 213-226.

Alloway, B.V., Almond, P., Augustinus, P., Barrell, D., Bertler, D., Carter, L., Litchfield, N., Lowe, D.J., McGlone, M.S., Newnham, R.M., Shulmeister, J., Vandergoes, M.J., Williams, P., NZ-INTIMATE Members, 2007. Towards a climate event stratigraphy for New Zealand over the past 30,000 years. Journal of Quaternary Science 22 (1), 9-35.

Anderson, B., Mackintosh, A., 2006. Temperature change is the major driver of late-glacial and Holocene glacier fluctuations in New Zealand. Geology 34, 121-124.

Barrows, T.T., Lehman, S.J., Fifield, L.K., De Deckker, P., 2007. Absence of cooling in New Zealand and the adjacent ocean during the Younger Dryas chronozone. Science 318, 86-89.

Birks, H.J.B., 2003. Quantitative palaeoenvironmental reconstructions from Holocene biological data. In: Mackay, A., Battarbee, R.W., Birks, H.J.B., Oldfield, J.S. (Eds.), Global Change in the Holocene. Arnold, London, pp. 107-123.

Blaauw, M., Christen, J.A., 2005. Radiocarbon peat chronologies and environmental change. Applied Statistics 54, 805-816.

Blunier, T., Brook, E.J., 2001. Timing of millennial-scale climate change in Antarctica and Greenland during the last glacial period. Science 291, 109-113.

Boothroyd, I.K.G., 1994. Description of Naonella n. gen (Diptera: Chironomidae: Orthocladiinae). New Zealand Journal of Zoology 21, 309-315.

Boothroyd, I.K.G., 1999. Description of Kaniwhaniwhanus gen. N. (Diptera: Chironomidae: Orthocladiinae) from New Zealand. New Zealand Journal of Marine and Freshwater Research 33, 341-349.

Boothroyd, I.K.G., 2002. Cricotopus and Paratricocladius (Chironomidae: Insecta) in New Zealand, with description of C. hollyfordensis $\mathrm{n}$. sp., and redescriptions of adult and immature stages of $C$. zealandicus and P. pluriserialis. New Zealand Journal of Marine and Freshwater Research 36, 775-778. 
Boothroyd, I.K.G., 2004. A new species of Naonella Boothroyd (Chironomidae: Orthocladiinae) from New Zealand. New Zealand Entomologist 27, 11-15.

Brooks, S.J., Birks, H.J.B., 2000. Chironomid-inferred late-glacial air temperatures at Whitrig Bog, Southeast Scotland. Journal of Quaternary Science 15, 759-764.

Burrows, C.J., Russell, J.B., 1990. Aranuian vegetation history of the Arrowsmith Range, Canterbury 1. Pollen diagrams, plant macrofossils, and buried soils from Prospect Hill. New Zealand Journal of Botany 28, 323-345.

Chinn, T.J., 1999. New Zealand glacier response to climate change of the past 2 decades. Global and Planetary Change 22, 155-168.

Clare, G.R., Fitzharris, B.B., Chinn, T.J., Salinger, M.J., 2002. Interannual variation in end-of-summer snowlines of the Southern Alps of New Zealand, and relationships with Southern Hemisphere atmospheric circulation and sea surface temperature patterns. International Journal of Climatology 22, 107-120.

Denton, G.H., Hendy, C.H., 1994. Younger Dryas age advance of Franz Josef Glacier in the Southern Alps, New Zealand. Science 264, 1434-1437.

Dieffenbacher-Krall, A.C., Vandergoes, M.J., Denton, G.H., 2007. An inference model for mean summer air temperatures in the Southern Alps, New Zealand using subfossil chironomids. Quaternary Science Reviews 26, 2487-2504.

EPICA Community Members, 2006. One-to-one coupling of glacial climate variability in Greenland and Antarctica. Nature 444, 195-197.

Faegri, K., Kaland, P.E., Krzywinski, K., 1989. Textbook of Pollen Analysis, fourth ed. Wiley, London.

Forsyth, D.J., 1971. Some New Zealand Chironomidae (Diptera). Journal of the Royal Society of New Zealand 1, 113-144.

Hajdas, I., Bonani, G., Moreno, P.I., Ariztegui, D., 2003. Precise radiocarbon dating of late glacial cooling in mid-latitude South America. Quaternary Research 59, 70-78.

Hajdas, I., Lowe, D.J., Newnham, R.M., Bonani, G., 2006. Timing of the late-glacial climate reversal in the Southern Hemisphere using high resolution radiocarbon chronology for Kaipo bog, New Zealand. Quaternary Research 65, 340-345.

Hellstrom, J., McCulloch, M., Stone, J., 1998. A detailed 13,000-year record of climate and vegetation change, from the isotope geochemistry of two New Zealand speleothems. Quaternary Research 50, $167-178$.

Heusser, C.J., 1998. Deglacial paleoclimate of the American sector of the Southern Ocean: Late glacial Holocene records from the latitude of Canal Beagle ( $\left.55^{\circ} \mathrm{S}\right)$, Argentine Tierra del Fuego. Palaeogeography, Palaeoclimatology, Palaeoecology 102, 53-68.

Ivy-Ochs, S., Schlüchter, C., Kubik, P.W., Denton, G.H., 1999. Moraine exposure dates imply synchronous Younger Dryas glacier advances in the European Alps and in the Southern Alps of New Zealand. Geografiska Annaler 81, 313-323.

Jouzel, J., Masson, V., Cattani, O., Falourd, S., Stievenard, M., Stenni, B., Longinelli, A., Johnsen, S.J., Steffenssen, J.P., Petit, J.R., Schwander, J., Souchez, R., Barkov, N.I., 2001. A new $27 \mathrm{ky}$ high resolution East Antarctic climate record. Geophysical Research Letters 28, 3199-3202.

Lamont, G.N., Chinn, T.J., Fitzharris, B.B., 1999. Slopes of glacier ELAs in the Southern Alps of New Zealand in relation to atmospheric circulation patterns. Global and Planetary Change 22, 209-219.

Lamy, F., Kaiser, J., Ninnemann, U., Hebeln, D., Arz, H., Stoner, J., 2004. Antarctic timing of surface water changes off Chile and Patagonian Ice Sheet response. Science 304, 1959-1962.

Large, M.F., Braggins, J.E., 1991. Spore Atlas of New Zealand Ferns and Fern Allies. SIR Publishing, Wellington, 168pp.

Leathwick, J.R., Wilson, G., Stephens, R.T.T., 1998. Climate surfaces for New Zealand. Landcare Research Contract Report, LC9798. Landcare Research, Hamilton, New Zealand.

McCormac, F.G., Reimer, P.J., Hogg, A.G., Higham, T.F.G., Baillie, M.G.L., Palmer, J., Stuiver, M., 2002. Calibration of the radiocarbon time scale for the Southern Hemisphere: AD 1850-950. Radiocarbon 44 (3), 641-651.

McCulloch, R.D., Bentley, M.J., Purves, R.S., Sugden, D.E., Clapperton, C.M., 2000. Climatic interferences from glacial and palaeocological evidence at the last glacial termination, southern South America. Journal of Quaternary Science 15, 409-417.

McCulloch, R.D., Fogwill, C.J., Sugden, D.E., Bentley, M.J., Kubik, P.W., 2005. Chronology of the Last Glaciation in Central Strait of Magellan and Bahía Inútil, southernmost South America. Geografiska Annaler 87A, 289-312.

McGlone, M.S., 1995. Lateglacial landscape and vegetation change and the Younger Dryas climatic oscillation in New Zealand. Quaternary Science Reviews 14, 867-881.

McGlone, M.S., 2001. The origin of the indigenous grasslands of southeastern South Island in relation to pre-human woody ecosystems. New Zealand Journal of Ecology 25, 1-15.

McGlone, M.S., Moar, N.T., 1998. Dryland Holocene vegetation history, Central Otago and the Mackenzie Basin, South Island, New Zealand. New Zealand Journal of Botany 36, 91-111.

McGlone, M.S., Turney, C.S.M., Wilmshurst, J.M., 2004. Lateglacial and Holocene vegetation and climatic history of the Cass Basin, central South Island, New Zealand. Quaternary Research 62, 267-279.

Martin, J., Forsyth, D., 2006. New Zealand Chironomus Species: Larval types and Karyotypes. 〈http://www.genetics.unimelb.edu.au/martin/ NZchirfile/NZChiron.htm $\rangle$.

Moar, N.T., 1971. Contributions to the Quaternary history of the New Zealand flora. 6. Aranuian pollen diagrams from Canterbury, Nelson, North Westland, South Island. New Zealand Journal of Botany 9, 80-145.

Moar, N.T., 1993. Pollen grains of New Zealand Dicotyledonous Plants. Maanaki Whenua Press, Lincoln, New Zealand, 200pp.

Moreno, P.I., Jacobson, G.L., Lowell, T.V., Denton, G.H., 2001. Interhemispheric climate linkages by a late-glacial cooling episode in southern Chile. Nature 409, 804-808.

Mortyn, P.G., Charles, C.D., Ninnemann, U.S., Ludwig, K., Hodell, D.A., 2003. Deep sea sedimentary analogs for the Vostok ice core. Geochemistry, Geophysics and Geosystems 4, 8405-8426.

New Zealand National Climate Centre, 2007. 〈http://www.niwascience. co.nz/ncc $>$.

Newnham, R.M., Lowe, D.J., 2000. Fine-resolution pollen record of Lateglacial climate reversal from New Zealand. Geology 28, 759-762.

Newnham, R.M., Eden, D.N., Lowe, D.J., Hendy, C.H., 2003. Rerewhakaaitu Tephra, a land-sea marker for the Last Termination in New Zealand, with implications for global climate change. Quaternary Science Reviews 22, 289-308.

Newnham, R.M., Lowe, D.J., Giles, T.M., Alloway, B.V., 2007a. Vegetation and climate of Auckland, New Zealand, since ca. 32,000 calyr ago: support for an extended LGM. Journal of Quaternary Science 22, 517-534.

Newnham, R.M., Vandergoes, M.J., Hendy, C.H., Lowe, D.J., Preusser, F., 2007b. A terrestrial palynological record for the last two glacial cycles from southwestern New Zealand. Quaternary Science Reviews 26, 517-535.

Pahnke, K., Zahn, R., 2005. Southern Hemisphere water mass conversion linked with North Atlantic climate variability. Science 307, 1741-1746.

Pahnke, K., Zahn, R., Elderfield, H., Schulz, M., 2003. 340,000-Year centennial-scale marine record of southern hemisphere climatic oscillation. Science 301, 948-952.

Pocknall, D.T., 1981a. Pollen morphology of the New Zealand species of Dacrydium Solander, Podocarpus L'Heritier, and Dacrycarpus Endlicher (Podocarpaceae). New Zealand Journal of Botany 19, 67-95.

Pocknall, D.T., 1981b. Pollen morphology of the New Zealand species of Libocedrus endlicher (Cupressaceae) and Agathis salisbury (Araucariaceae). New Zealand Journal of Botany 19, 267-272.

Pocknall, D.T., 1981c. Pollen morphology of Phyllocladus L C. et A. Rich. New Zealand Journal of Botany 19, 259-266.

Petit, J.R., Jouzel, J., Raynaud, D., Barkov, N.I., Barnola, J.-M., Basile, I., Benders, M., Chappellaz, J., Davis, M., Delaygue, G., Delmotte, 
M., Kotlyakov, V.M., Legrand, M., Lipenkov, V.Y., Lorius, C., Pe' pin, L., Ritz., C., Saltzman, E., Stievenard, M., 1999. Climate and atmospheric history of the past 420,000 years from the Vostok ice core, Antarctica. Nature 399, 429-436.

Reimer, P.J., Baillie, M.G.L., Bard, E., Bayliss, A., Beck, J.W., Bertrand, C.J.H., Blackwell, P.G., Buck, C.E., Burr, G.S., Cutler, K.B., Damon, P.E., Edwards, R.L., Fairbanks, R.G., Friedrich, M., Guilderson, T.P., Hogg, A.G., Hughen, K.A., Kromer, B., McCormac, G., Manning, S., Bronk Ramsey, C., Reimer, R.W., Remmele, S., Southon, J.R., Stuiver, M., Talamo, S., Taylor, F.W., van der Plicht, J., Weyhenmeyer, C.E., 2004. IntCal04 terrestrial radiocarbon age calibration, 0-26 cal kyr BP. Radiocarbon 46, 1029-1058.

Schaefer, J.M., Denton, G.H., Barrell, D.J.A., Ivy-Ochs, S., Kubic, P.W., Anderson, B.G., Phillips, F.M., Lowell, T.V., Schluchter, C., 2006. Mid-latitude moraines reveal near-synchronous interhemispheric termination of the Last Glacial Maximum. Science 312, 1510-1513.

Stark, J.D., Winterbourn, M.J., 2006. Chironomidae (nonbiting midges). In: Winterbourn, M.J., Gregson, K.L.D., Dolphin, C.H. (Eds.), Guide to the Aquatic Insects of New Zealand. Bulletin of the Entomological Society of New Zealand 14, 76-84.

Sugden, D.E., Bentley, M.J., Fogwill, C.J., Hulton, N.R.J., McCulloch, R.D., Purves, R.S., 2005. Late-Glacial glacier events in southernmost South America: a blend of 'Northern' and 'Southern' hemispheric climatic Signals? Geografiska Annaler 87A, 273-288.

Turney, C.S.M., McGlone, M.S., Wilmshurst, J.M., 2003. Asynchronous climate change between New Zealand and the North Atlantic during the last deglaciation. Geology 31, 223-226.
Vandergoes, M.J., Fitzsimons, S.J., 2003. The last glacial-interglacial transition (LGIT) in south westland, New Zealand: paleoecological insight into mid-latitude southern hemisphere climate change. Quaternary Science Reviews 22, 1461-1476.

Vandergoes, M.J., Newnham, R.M., Hendy, C.H., Lovell, T.V., Preusser, F., Fitzsimons, S.J., Hogg, A., Kasper, H.U., Schlüchter, C., 2005. Regional insolation forcing of late Quaternary climate change in the Southern Hemisphere. Nature 436, 242-245.

Walker, I.R., Mott, R.J., Smol, J.P., 1991. Allerød-Younger Dryas lake temperatures from midge fossils in Atlantic Canada. Science 253, 1010-1012.

Wardle, P., 1991. Vegetation of New Zealand. Cambridge University Press, London.

Williams, P.W., King, D.N.T., Zhao, J.X., Collerson, K.D., 2005. Late Pleistocene to Holocene composite speleothem ${ }^{13} \mathrm{C}$ and ${ }^{18} \mathrm{O}$ chronologies from South Island, New Zealand - did a global Younger Dryas really exist? Earth and Planetary Science Letters 230, 301-317.

Wilmshurst, J.M., McGlone, M.S., Leathwick, J.R., Newnham, R.M., 2007. A pre-deforestation pollen-climate calibration model for New Zealand and quantitative temperature reconstructions for the past 18,000 years BP. Journal of Quaternary Science 22, 535-547.

Woodward, C.A., Shulmeister, J., 2006. New Zealand chironomids as proxies for human-induced and natural environmental change: transfer functions for temperature and lake production (chlorophyll a). Journal of Paleolimnology 36, 407-429. 